Volume 1 Nomor 1, Juli-Desember 2017: hlm. 11-18. Magister Ilmu Hukum, Fakultas Hukum, Universitas Lampung, Bandar Lampung, Lampung, Indonesia. E-ISSN: 2598-3105 P-ISSN: 2723-2581

http://jurnal.fh.unila.ac.id/index.php/cepalo

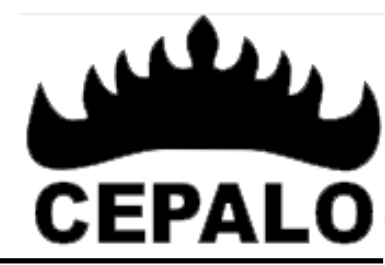

\title{
ANALISIS EKSISTENSI CLOSED CIRCUIT TELEVISION (CCTV) PADA PEMBUKTIAN PERKARA TINDAK PIDANA UMUM
}

\author{
ANALYSIS OF CLOSED CIRCUIT TELEVISION (CCTV) AS EVIDENCE IN \\ VERIFICATION OF CRIMINAL CASE
}

\author{
Rivaldo Valini \\ Kejaksaan Negeri Bandar Lampung \\ aldojks@gmail.com
}

\begin{abstract}
Abstrak
Eksistensi CCTV pada pembuktian perkara tindak pidana umum adalah dapat menjadi alat bukti yang sah apabila dilakukan dalam rangka penegakan hukum atas permintaan kepolisian, kejaksaan, dan/atau institusi penegak hukum lainnya yang diitetapkan berdasarkan undang-undang. CCTV dijadikan alat bukti dalam Hukum Pidana Indonesia merupakan suatu kebijakan kriminal dengan menggunakan sarana penal dan non penal. Dalam Hukum Pidana Indonesia, penggunaan CCTV sebagai alat bukti termasuk dalam kebijakan dengan Sarana Non Penal yang merupakan suatu cara yang digunakan oleh aparat penegak hukum dalam mengatasi belum adanya pengaturan dalam KUHAP. Kebijakan Pidana dengan Sarana Penal, merupakan tindakan nyata aparat penegak hukum, khususnya setelah diberlakukan Putusan Mahkamah Konstitusi (MK) Nomor: 21/PUU- XIV/2016.
\end{abstract}

Kata Kunci: Eksistensi CCTV, Pembuktian, Pidana Umum.

\section{Abstract}

In criminal case, Closed Circuit Television (CCTV) could be legal evidence if it intended of law enforcement at the instance of polices, attorney, and/or other legal institution which based on laws. Under Indonesia criminal laws, CCTV qua legal evidence as a part of criminal policy in penal and non-penal means to answer legal requirement wherein Indonesia Criminal Rules of Procedures (KUHAP) order yet. Whereas criminal policy in penal means obvious action of enforcement subsequent to Indonesia Constitution Court Decision number 21/PUUXIV/2016.

Keywords: Closed Circuit Television (CCTV), Verification, Criminal Case.

Cara Mengutip (How to Cite): Rivaldo Valini, "Analisis Eksistensi Closed Circuit Television (CCTV) Pada Pembuktian Perkara Tindak Pidana Umum”, Jurnal Cepalo, 1 (1), (2017): 11-18.

DOI: https://doi.org/10.25041/cepalo.v1no1.1751

\section{A. Pendahuluan}

Penegakan hukum berperan sangat penting dalam menjamin kepentingan kehidupan bermasyarakat. Terjaminnya kepastian hukum, semua tindak kriminal dan perbuatan sewenangwenang yang dilakukan masyarakat dapat terhindarkan. Pentingnya masalah penegakan hukum berkaitan dengan maraknya beragam fenomena kejahatan baik dari jumlah dan mutu serta mengalami kerumitan baik dari segi bentuk, sifat, keadaan, modus serta peluknya. Keberadaan dimana dan kapan terjadinya kejahatan sudah tidak mampu lagi diprediksi karena telah melekat 
dalam kehidupan sehari-hari. ${ }^{1}$

Salah satu perangkat penegak hukum adalah Polri yang memiliki tugas menjaga dan melindungi negara dengan menjalankan bermacam peran dari polisi yang termasuk diantaranya menjaga keamanan dan ketertiban dalam bermasyarakat, penegakkan hukum, memberikan perlindungan, pengayoman, dan pelayanan kepada masyarakat selaku aparat negara yang menjunjung tinggi hak asasi manusia dibantu dengan masyarakat. ${ }^{2}$

Hal ini sesuai dengan Pasal 13 Undang-Undang Nomor 2 Tahun 2002 tentang Kepolisian Negara Republik Indonesia bahwa Tugas pokok Kepolisian Negara Republik Indonesia adalah memelihara keamanan dan ketertiban masyarakat, menegakkan hukum, dan memberikan perlindungan, pengayoman, dan pelayanan kepada masyarakat. Proses penegakan hukum oleh Kepolisian tidak dapat dipisahkan dari berkembangnya ilmu pengetahuan dan teknologi, misalnya adalah alat perekam berupa kamera tersembunyi atau Closed Circuit Television (CCTV). Dalam konteks ini kepolisian dapat menjadikan rekaman CCTV sebagai salah satu alat bukti. Sesuai dengan ketentuan Pasal 184 ayat (1) KUHAP, alat bukti yang sah ialah keterangan saksi, keterangan ahli, surat, petunjuk dan keterangan terdakwa. Maknanya adalah alat bukti di luar ketetapan KUHAP tersebut tidaksah.

Permasalahan hukum dalam penelitian ini adalah sesuai ketentuan Pasal 184 ayat(1) KUHAP maka rekaman CCTV atas terjadinya tindak pidana atau kejahatan tidak memiliki legalitas atau tidak sah, sehingga di peradilan umum tidak bisa dijadikan alat bukti, karena dalam Pasal 184 Ayat (1) KUHAP sudah ditetapkan alat bukti yang sah secara terbatas, sehingga hasil rekaman video hanya dijadikan pelengkap alat bukti lainnya atau alat bukti petunjuk, yang penilaian atas kekuatannya dilakukan oleh hakim sebagaimana yang diterangkan oleh Pasal 188 KUHAP. Dengan kata lain, rekaman CCTV pada dasarnya tidak dapat diajukan sebagai alat bukti berdasarkan Pasal 184 ayat (1) KUHAP, dan tidak ada aturan mengenai legalitas hasil cetak atau print out sebagai alat bukti atau tata cara mengajukan alat bukti berupa informasi elektronik. Dengan demikian untuk tindak pidana umum belum ada pengaturan secara khusus mengenai keabsahan hasil rekaman CCTV sebagai salah satu alat bukti.

Diakuinya penggunaan informasi atau berkas elektronik sebagai alat bukti baru pada beberapa tindak pidana khusus di antaranya adalah setelah diundangkannya Undang-Undang Nomor 20 Tahun 2001 tentang Pemberantasan Tindak Pidana Korupsi. Pasal 26 A menyebutkan bahwa alat bukti yang di simpan secara elektronik dianggap sah dalam kasus tindak pidana korupsi. Selain itu, disebutkan juga di dalam Pasal 38 huruf b Undang-Undang Nomor 15 Tahun 2002 tentang Tindak Pidana Pencucian Uang dan Pasal 27 huruf b Undang-Undang Nomor 15 Tahun 2003 tentang Pemberantasan Tindak Pidana Terorisme. Hal ini menunjukkan bahwa masih terbatasnya legalitas dan keberlakuan informasi elektronik sebagai alat bukti, hanya pada beberapa tindak pidana khusus saja. ${ }^{3}$

Penggunaan informasi atau dokumen elektronik semakin jelas dasar hukumnya sebagai alat bukti di pengadilan setelah diundangkannya Undang-Undang Nomor 11 Tahun 2008 tentang Informasi dan Transaksi Elektronik, yang dapat memberikan kepastian hukum keberlakuannya, tidak hanya delik luar saja. Selain itu, undang-undang ini dalam Pasal 5 Ayat (1) disebutkan informasi dan/atau dokumen elektronik dan/atau hasil cetaknya merupakan alat bukti hukum yang sah.

Sesuai dengan uraian di atas diketahui bahwa dalam beberapa undang-undang tindak pidana khusus, alat bukti rekaman data elektronik telah diaturnya, tetapi untuk tindak pidana umum, yang menggunakan KUHAP sebagai acara pidananya masih mengacu pada ketentuan Pasal 184 Ayat (1) KUHAP, ada lima alat bukti yaitu: keterangan saksi, keterangan ahli, surat, petunjuk, dan keterangan terdakwa. Secara subjektif dapat dinyatakan bahwa perumusan kurang relevan dengan kemajuan ilmu pengetahuan dan teknologi dan tidak akomodatif terhadap perkembangan yang semakan maju. Selama ini rekaman CCTV masih belum jelas kedudukannya, rekaman data elektronik khususnya video dapat memiliki nilai tetapi pengakuannya menjadi perdebatan

\footnotetext{
${ }^{1}$ Barda Nawawi Arief, Masalah Penegakan Hukum dan Kebijakan Penanggulangan Kejahatan, Bandung: Citra Aditya Bakti, (2001), hlm.6.

${ }^{2}$ Lilik Mulyadi, Hukum Acara Pidana, Bandung: Citra Aditya Bakti, (2007), hlm. 152-153.

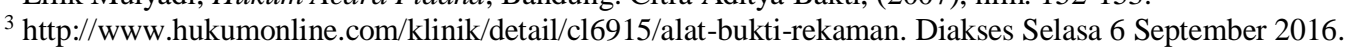


dalam pembuktian perkara pidana umum. ${ }^{4}$

Dalam kemajuan dari penegakan hukum, penerapan teknologi dijadikan bukti permulaan yang cukup dan suatu bentuk asas praduga tidak bersalah (presumption of innocent) dengan kekuatan hukum tetap, dimana rekaman CCTV tersebut, akan meyakinkan penyidik bahwa seseorang bersalah, sehingga mengurangi penyalahgunaan asas presumption of innocent tersebut. Isu hukum didalam penelitian ini adalah pada umumnya dalam perkara-perkara tindak pidana di mana tersangka/terdakwa didampingi penasehat hukum, CCTV tidak diakui sebagai alat bukti. Sebaliknya untuk perkara-perkara tindak pidana dimana tersangka/terdakwa tidak didampingi penasehat hukum, CCTV diakui sebagai alat bukti, khususnya alat bukti petunjuk. Hal ini terlihat dalam perkara tindak pidana korupsi yang melibatkan Setya Novanto, Mahkamah Konstitusi (MK) dalam putusan Nomor: 21/PUU-XIV/2016 menyebutkan bahwa semua bukti elektronik yang bukan diambil oleh aparat penegak hukum, tidak mempunyai kekuatan hukum. Padahal dalam kenyataannya rekaman CCTV digunakan aparat penegak hukum untuk memperkuat pembuktian persidangan. Permasalahan penelitian ini adalah bagaimana eksistensi CCTV pada pembuktian perkara tindak pidana umum? Dan Bagaimanakah kebijakan kriminal tentang CCTV sebagai alat bukti dalam hukumpidana? Penelitian ini menggunakan pendekatan yuridis normatif dan pendekatan yuridis empiris. Informan dalam penelitian ini terdiri dari Penyidik pada Polresta Bandar Lampung, Personil Bagian IT Polda Lampung, Jaksa pada Kejaksaan Negeri Bandar Lampung, Hakim pada Pengadilan Negeri Tanjung Karang dan Akademisi Hukum Pidana pada Fakultas Hukum Unila. Data dikumpulkan melalui studi kepustakaan dan studi lapangan, selanjutnya dianalisis secara kualitatif.

\section{B. Pembahasan}

\section{Eksistensi CCTV pada Pembuktian Perkara Tindak Pidana Umum}

Proses penegakan hukum pidana tidak dapat dipisahkan dengan berkembangnya ilmu pengetahuan dan teknologi, contohnya penggunaan Closed Circuit Television (CCTV). CCTV adalah penggunaan kamera video untuk mentransmisikan signal video ke tempat spesifik, dalam beberapa set monitor. CCTV paling banyak digunakan untuk pengawasan pada area yang memerlukan pengawasan.Dalam konteks yang demikian maka eksistensi CCTV didalam pemeriksaan perkara di persidangan yaitu sebagai alat bukti pada proses pembuktian. Pembuktian merupakan suatu cara dengan memberikan alat bukti yang menurut undang-undang yang digunakan hakim untuk membuktikan bersalah atau tidaknya terdakwa yang sebagaimana diatur dalam Pasal 184 ayat (1) KUHAP, bahwa alat bukti terdiri dari keterangan dari terdakwa, saksi, dan para ahli, surat serta petunjuk.

Pesatnya kemajuan ilmu pengetahuan dan teknologi saat ini, khususnya di bidang telekomunikasi, informasi dan komputer, dan berkembangnya kehidupan sosial dan teknologi yang membuat manusia menjadi sering menggunakan teknologi dalam kehidupan termasuk dalam hal berkomunikasi. Sistem informasi saat ini menggunakan sistem elektronik dalam menyusun, memproses, menganalisis, dan mengirim atau menyebarluaskan informasi elektronik yang merupakan bagian dari teknologi informasi itu sendiri.

Menurut Akhmad Suhel ${ }^{5}$ CCTV dibutuhkan dalam suatu persidangan sebagai pelengkap untuk membuktian kejadian-kejadian yang terjadi agar dapat diperlihatkan atau ditontonkan di muka persidangan, namun masih dibutuhkannya keabsahan dari CCTV ini. Keabsahan ini berupa sesuatu yang diyakini pengakuannya benar, legal dan sah. Tidak ada keraguan didalam keabsahan dan hal ini legal menurut Undang-Undang. Apabila Substansi yang terdapat didalam alat bukti sudah terpenuhi syaratnya, maka bukti harus cukup, sesuai dan cakap dalam pengujian bukti pemeriksaan.

Eko Setiawan ${ }^{6}$ menjelaskan bahwa untuk memastikan asli atau tidaknya alat bukti rekaman tersebut maka diperlukan audit terhadap sistem informasi. Apabila sistem informasi tersebut

\footnotetext{
${ }^{4}$ Marselus Pasha Lelyemin, F. Nugroho dan Edy Hartadi, Kedudukan Rekaman Video sebagai Alat Bukti Dalam Hukum Acara Pidana di Indonesia, Jakarta: Fakultas Hukum Unika Atmajaya, (2007), hlm. 24.

${ }^{5}$ Hasil wawancara dengan Akhmad Suhel. Hakim Pengadilan Negeri Tanjung Karang. Rabu, 18 Januari 2017.

${ }^{6}$ Hasil wawancara dengan Eko Setiawan. Personil Bagian IT Polda Lampung. Kamis, 19 Januari 2017.
} 
sudah diaudit oleh badan yang telah ditetapkan, maka rekaman tersebut bisa langsung dijadikan alat bukti dan tidak bisa disangkal lagi. Apabila sistem informasi belum pernah diaudit maka harus secepatnya dilakukan audit. Alat bukti harus memperoleh pengesahan dari biro hukum. Bukti-bukti sebaiknya dicatatkan dalam Berita Acara Pengalihan Dokumen, apabila alat bukti rekaman dialihkan dalam CD yang berisi file microsoft power point, DVD-R, CD-R atau jenis pengalihan lainnya.

Eva Mayanti ${ }^{7}$ menambahkan bahwa keabsahan alat bukti dapat diperkuat dengan keterangan dari orang-orang yang terlibat. Sidang pengadilan tidak bisa dilakukan sembarangan dalam membuktikan kesalahan terdakwa karena sulitnya mencari kebenaran materiil. Alat bukti yang ada didalam undang-undang tidaklah mutlak. Alat bukti seperti kesaksian, menjadi tidak jelas dan tidak mutlak. Kesaksian merupakan informasi yang diberikan oleh manusia yang pada dasarnya memiliki sifat pelupa. Kesaksian yang diberikan bisa saja berbeda-beda setiap orang dalam suatu peristiwa.

Pengadaan alat bukti di dalam suatu peradilan perkara pidana dapat memberikan titik terang dalam proses pembuktiannya. Ada beberapa cara membuktikan gambaran akan suatu kejadian, salah satunya adalah hasil dari sebuah rekaman CCTV dapat membantu dalam prose pembuktian suatu perkara dengan memberikan gambaran terhadap kejadian disuatu tempat secara terperinci dan jelas tanpa rekayasa.

Akhmad Suhel ${ }^{8}$ menjelaskan rekaman CCTV memiliki peranan yang sangat penting dalam suatu proses persidangan pada tahap pembuktian tindak pidana untuk mengungkap kejadian yang sebenarnya terjadi di tempat kejadian perkara. Hasil dari putusan Pengadilan menyatakan bahwa dalam mengungkap kejadian yang sebenarnya terjadi dilapangan, hasil rekaman CCTV memiliki peranan penting dan hal ini diakui oleh para saksi dan terdakwa. Namun tidak dapat dipungkiri bahwa alat bukti lainnya juga memiliki peran yang sangat penting dalam pembuktian suatu perkara. Penggunaan CCTV juga menjadi hal yang dianggap penting bagi masyarakat untuk menghindari terjadinya tindak pidana.

Penggunaan rekaman CCTV dalam pembuktian tindak pidana umum ditandai dengan adanya Putusan Mahkamah Konstitusi (MK) dalam Nomor: 21/PUU- XIV/2016 menyebutkan bahwa semua bukti elektronik yang bukan diambil oleh aparat penegak hukum, tidak mempunyai kekuatan hukum. Padahal dalam kenyataannya rekaman CCTV digunakan oleh aparat penegak hukum untuk memperkuat pembuktian persidangan. Adapun dasar pembuktian CCTV dikaitkan dengan Putusan Mahkamah Konstitusi Nomor 20/PUU-XIV/2016 tentang CCTV sebagai alat bukti elektronik.

Sesuai keputusan MK informasi elektronik termasuk rekaman kamera CCTV, tidak mempunyai kekuatan hukum mengikat sepanjang tidak dimaknai khususnya frasa "Informasi Elektronik dan/atau Dokumen Elektronik" sebagai alat bukti dilakukan dalam rangka penegakan hukum atas permintaan kepolisian, kejaksaan, dan/atau institusi penegak hukum lainnya yang ditetapkan berdasarkan undang-undang. Artinya, rekaman kamera CCTV bisa menjadi alat bukti yang sah apabila dilakukan dalam rangka penegakan hukum atas permintaan kepolisian, kejaksaan, dan/atau institusi penegak hukum lainnya yang diitetapkan berdasarkan undangundang.

Selain itu pengambilan data/rekaman CCTV harus didampingi oleh penyidik dan dibuatkan berita acara. Alat bukti ini digunakan dalam mendukung proses peradilan yang menunjukkan secara jelas kejadian di tempat perkara, sehingga untuk mendapatkan suatu kebenaran dalam proses peradilan, rekaman CCTV berguna sebagai alat bukti penunjang pembuktian disamping alat-alat bukti lain. Selain keterangan saksi dan keterangan terdakwa, rekaman CCTV dapat meyakinkan hakim dalam memberikan putusan. Kepolisian dan Kejaksaan bertugas dalam memeriksa keaslian dari setiap alat bukti yang ada sehingga tidak merugikan pihak lain. Berdasarkan hukum acara yang ada di Indonesia, informasi dan dokumen elektronik serta hasil cetaknya dianggap alat bukti yang sah.

\footnotetext{
${ }^{7}$ Hasil wawancara dengan Eva Mayanti. Penuntut Umum pada Kejaksaan Negeri Bandar Lampung. Senin, 16 Januari 2017.

${ }^{8}$ Hasil wawancara dengan Akhmad Suhel. Hakim Pengadilan Negeri Tanjung Karang. Rabu, 18 Januari 2017.
} 
Berdasarkan penjelasan tersebut, dinyatakan bahwa eksistensi CCTV pada pembuktian suatu tindak pidana adalah sebagai suatu alat bukti petunjuk yang bisa dipergunakan hakim sebagai dasar untuk menjatuhkan pidana. Dalam hal ini, CCTV digunakan dalam membantu proses peradilan untuk menunjukkan secara jelas kejadian di lokasi perkara. Dalam konteks tindak pidana umum seperti pencurian, rekaman CCTV mampu memberikan keyakinan kepada hakim dalam memutus perkara. Hal ini menjelaskan bahwa, semakin berkembangnya teknologi saat ini, memberikan dampak yang besar bagi penegak hukum di Indonesia dalam menyelesaikan suatu perkara pidana hanya melalui rekaman CCTV.

\section{Kebijakan Kriminal tentang CCTV sebagai Alat Bukti dalam Hukum Pidana}

Kebijakan kriminal tentang CCTV sebagai suatu alat bukti dalam hukum pidana di Indonesia memiliki kaitan dengan UU ITE dan Putusan Mahkamah Konstitusi Nomor 20/PUUXIV/2016 tanggal 7 September 2016. CCTV termasukdalamdefinisi informasi dan dokumen elektronik sebagaimana dimaksud dalam Pasal 1 butir 1 dan 4 UU ITE dan menjadi alat bukti yang sah, sehingga dalam hukum acara pidana bisa digunakan sebagai alat bukti dalam proses penyidikan, penuntutan dan persidangan sebagaimana diatur dalam Pasal 5 ayat (1) dan (2) serta Pasal 44 UU ITE. Penjelasan pasal tersebut Putusan Mahkamah Kontitusi menyatakan bahwa frase informasi elektronik dan/atau data elektronik dalam Pasal 5 ayat (1) dan (2) serta Pasal 44 UU ITE bertentangan dengan Undang-Undang Dasar Negara Republik Tahun 1945 (UUD 1945) yang artinya tidak memiliki kekuatan hukum mengikat sepanjang tidak diartikan secara khusus dalam frase informasi elektronik dan/atau data elektronik sebagai alat bukti untuk menegakkan hukum atas permintaan para penegak hukum yang ditetapkan berdasarkan undangundang sebagaimana diatur dalam Pasal 31 ayat (3) UU ITE. Di dalam hukum acara pidana, Putusan Mahkamah Konstitusi tersebut yang menjadi landasan pembatasan penggunaan CCTV sebagai alatbukti.

Menurut Eva Mayanti ${ }^{9}$ peran dari informasi dan dokumen elektronik dalam hukum acara pidana di Indonesia telah menimbulkan pertanyaan sebelum adanya putusan Mahkamah Konstitusi tersebut. Jika dianalisis, ketentuan Pasal 5 ayat (2) UU ITE tersebut mengatakan bahwa berdasarkan hukum acara yang ada, keduanya termasuk perluasan dari alat bukti yang sah. Perluasan disini tidak dijelaskan lebih lanjut sehingga timbul berbagai pertanyaan terkait maksud dari perluasan tersebut. Dalam Pasal 184 KUHAP terdapat lima alat bukti yang sah yaitu keterangan dari saksi, ahli, dan terdakwa, surat, serta petunjuk dan apabila perluasan ini diartikan sebagai penambahan maka alat bukti dalam hukum acara pidana di Indonesia menjadi lebih dari lima. Bisa atau tidaknya informasi elektronik dan data elektronik menjadi landasan petunjuk bagi Majelis Hakim merupakan pertanyaan yang timbul selanjutnya. Jika perluasan ini diartikan sebagai bagian dari alat bukti yang ada maka informasi dan dokumen elektronik akan dimasukkan dalam alat bukti petunjuk atau alat bukti surat.

Menurut Akhmad Suhel ${ }^{10}$ informasi dan data elektronik merupakan bagian dari alat bukti petunjuk, pengaturan CCTV tidak termasuk dalam alat bukti sifatnya terbatas dalam Pasal 184 KUHAP tetapi termasuk sebagai bagian dari alat bukti petunjuk dalam meyakinkan hakim. Pendapat ini didasarkan pada pandangan hukum acara pidana modern yang menyatakan barang bukti dan alat bukti termasuk dalam bukti.

Hal ini didasarkan pada pengaturan mengenai alat bukti lainnya yang bersifat elektronik dalam Pasal 26A Undang-Undang Nomor 20 Tahun 2001 tentang Perubahan Kedua atas Undang-Undang Nomor 31 Tahun 1999 tentang Pemberantasan Tindak Pidana Korupsi (UU Tipikor). Pasal ini mengatur dengan jelas bahwa alat bukti petunjuk termasuk juga didalamnya alat bukti lainnya yang bersifat elektronik. Pasal ini juga sudah diuji bersamaan dengan ketentuan Pasal 5 ayat (1) dan (2) serta Pasal 44 UUITE.

Menurut Eddy Rifai ${ }^{11}$ untuk dasar pembuktian CCTV harus dikaitkan dengan Putusan

\footnotetext{
${ }^{9}$ Hasil wawancara dengan Eva Mayanti. Penuntut Umum pada Kejaksaan Negeri Bandar Lampung. Senin, 16 Januari 2017.

${ }^{10}$ Hasil wawancara dengan Akhmad Suhel. Hakim Pengadilan Negeri Tanjung Karang. Rabu, 18 Januari 2017.

${ }^{11}$ Hasil wawancara dengan Eddy Rifai. Akademisi Hukum Pidana Fakultas Hukum Universitas Lampung. Sabtu, 4 Maret 2017.
} 
Mahkamah Konstitusi Nomor 20/PUU-XIV/2016 tentang CCTV sebagai alat bukti elektronik. Selain itu pengambilan data/rekaman CCTV harus didampingi oleh penyidik dan dibuatkan berita acara.

Putusan Mahkamah Konstitusi Nomor 20/PUU-XIV/2016 tanggal 7 September 2016 memutuskan bahwa kata informasi dan/atau data elektronik dalam Pasal26A UU Tindak pidana korupsi bertentangan dengan Undang-Undang Dasar 1945 yang artinya tidak memiliki kekuatan hukum mengikat sepanjang tidak diartikan secara khusus dalam kata informasi dan/atau data elektronik sebagai alat bukti untuk menegakkan hukum atas permintaan para penegak hukum berdasarkan ketetapan undang-undang sebagaimana diatur dalam Pasal 31 ayat (3)UUITE.Selaras dengan Putusan MK Nomor 20/PUU-XIV/2016 yang menyatakan barang bukti dan alat bukti memiliki peranan sebagai bagian dari bukti dimana harus didapat sesuai dengan ketetapan dalam peraturan perundang-undangan yang berlaku. Oleh sebab itu, informasi dan/atau dokumen elektronik merupakan bagian dari barang dalam suatu tindak pidana. Majelis hakim konstitusi juga menyatakan bahwa informasi dan/atau dokumen elektronik bisa dianggap sebagai alat bukti yang sah apabila didapat dengan cara yang sah pula, jika tidak maka bisa dikesampingkan. putusan Mahkamah Konstitusi ini menunjukkan penggabungan antara peranan atas alat bukti informasi dan dokumen elektronik dengan cara memperoleh yang tidak benar suatu alat bukti.

Dalam hal penggabungan, didalam Putusan Mahkamah Konstitusi Nomor 20/PUUXIV/2016, adanya pendapat yang berbeda atau diessenting opinion dari Hakim Konstitusi Suhartoyo sependapat dengan ahli Edmon Makarim, bahwa dibutuhkan pemisahan antara alat bukti dan cara memperolehnya, sehingga seluruh informasi dan/atau dokumen elektronik menjadi alat bukti yang sah walaupun cara memperolehnya dengan cara lain. Hakim Suhartoyo berpendapat bahwa di dalam UU ITE sudah diatur mengenai cara memperoleh alat bukti yang sah dari informasi dan/atau dokumen elektronik sehingga permohonan uji materi semestinya ditolak.

Menurut Kurnia Muludi ${ }^{12}$ pembuktian dengan menggunakan media CCTV harus diawali dengan pembuktian bahwa hasil rekaman CCTV tersebut adalah asli, hal ini dapat dilakukan dengan menggunakan teknik pengecekan originalitas. Sumber data CCTV harus dilakukan penyitaan oleh penyidik, agar tidak ada data elektronik yang dirubah dan diperlukan back up data CCTV dengan media penyimpanan eksternal (external storage) untuk mengamankan data dalam jangka waktu yang lama.

Di Indonesia, putusan Mahkamah Konstitusi tersebut mengubah tolak ukur suatu pembuktian. Keabsahan dalam memperoleh suatu alat bukti sebelumnya tidak diatur maka setelah putusan MK tersebut khusus untuk informasi dan dokumen elektronik, keabsahan dalam memperoleh suatu alat bukti sebagai alat bukti mempunyai nilai pembuktian atau tidak. Oleh sebab itu, dalam menggunakan CCTV untuk menjebak tindakan suap, tidak bisa diterima sebagai alat bukti yang sah sebagaimana didalam kasus tindak pidana korupsi atas nama terpidana Mulyana W Kusuma.

Kebijakan kriminal didalam Hukum Pidana Indonesia tentang CCTV sebagai alat bukti di berbagai peraturan perundang-undangan, sesuai dengan teori kebijakan kriminal (penal policy atau criminal policy) sebagai cara dalam mengatasi kejahatan dengan menegakkan hukum pidana. Penanggulangan kejahatan di berbagai sarana, pelaku kejahatan dapat dikenakan sanksi pidana maupun non pidana, yang bisa disesuaikan antara satu dengan lainnya. Jika sarana pidana digunakan untuk mengatasi kejahatan, berarti akan dilakukan politik hukum pidana, yaitu melakukan pemilihan agar tercapainya hasil undang-undang yang sesuai dengan kondisi sekarang dan masa yang akan datang. ${ }^{13}$

Usaha-usaha yang dilakukan dalam mengatasi kejahatan (politik kriminal) menggunakan 2 (dua) sarana, yaitu:

1. Kebijakan dengan Sarana Non Penal, dalam hal ini penggunaan CCTV sebagai alat bukti

\footnotetext{
${ }^{12}$ Hasil wawancara dengan Kurnia Muludi. Ahli Telematika Jurusan Ilmu Komputer Fakultas MIPA Universitas Lampung. Jumat, 3 Maret2017.

${ }^{13}$ Barda Nawawi Arif, Kebijakan Hukum Pidana, Bandung: Citra Aditya Bakti, (2004), hlm.12.
} 
merupakan upaya yang dilakukan oleh kepolisian dalam menanggulangi belum adanya pengaturan dalam KUHAP mengenai eksistensi CCTV dalam perkara tindak pidana.

2. Kebijakan Pidana dengan Sarana Penal, dalam hal ini penggunaan CCTV sebagai alat bukti merupakan tindakan nyata aparat penegak hukum, khususnya setelah diberlakukan Putusan Mahkamah Konstitusi (MK) Nomor: 21/PUU-XIV/2016 yang mengatur bahwa semua bukti elektronik yang bukan diambil oleh aparat penegak hukum, tidak mempunyai kekuatan hukum. Oleh karena itu penggunaan CCTV sebagai alat bukti harus diawali dengan proses pengambilan oleh aparat penegak hukum, yang dilegalisasi dengan pembuatan berita acara pengambilan alat bukti.

Undang-Undang ITE telah mengakui sahnya bukti elektronik sebagai alat bukti di Pengadilan, namun untuk memenuhi kepentingan dalam praktik peradilan, hal ini dirasabelumcukup, karena hanya berupa pengaturan hukum materiil.Dalam hal ini, diperlukan pengaturan bukti elektronik dalam hukum formal agar terbentuknya suatu kepastian hukum, karena dalam praktek peradilan menggunakan hukum acara sebagai hukum formal yang sifatnya mengikat.

Bukti elektronik haruslah diatur dan diakui sebagai alat bukti yang sah, mengingat dalam berpekara ke Pengadilan, Hukum Acara Perdata maupun hukum Acara Pidana memiliki sifat memaksa dan mengikat untuk Hakim ataupun pihak-pihak yang berperkara. Bukti elektronik sudah diatur didalam Rancangan Undang Undang Hukum Acara Perdata dengan dirumuskannya pengaturan tentang alat bukti secara terbuka, yang menetapkan bahwa: "pembuktian dapat dilakukan dengan semua alat bukti, kecuali undang- undang menentukan lain".

Walaupun belum adanya pengaturan yang tegas mengenai bukti elektronik didalam Hukum Acara Perdata ataupun Hukum Acara Pidana, tetapi hakim tetap tidak bisa menolak untuk memeriksa atau memutus suatu perkara dengan beralasan tidak jelasnya asas hukum atau pengaturannya karena hal ini bertentangan dengan asas peradilan, dimana nilai-nilai hukum yang ada dalam masyarakat harus digali lebih dalam oleh hakim. Maka Undang-Undang ITE dapat dijadikan sebagai dasar pengakuan sahnya bukti elektronik sebagai alat bukti di persidangan.

Sejak tahun 1977, bukti elektronik sudah diakui sebagai alat bukti yang sah bisa diajukan ke pengadilan melalui Undang Undang Dokumen Perusahaan yang menentukan bahwa apabila adanya gugatan maka rekaman dokumen perusahaan yang dialihkan ke dalam mikro film bisa dijadikan sebagai alat bukti di Pengadilan. Hal ini dipertegas dengan adanya UU ITE. Oleh karenanya, berdasarkan Hukum Acara di Indonesia, bukti elektronik sudah diakui sebagai alat bukti hukum yang sah, dan termasuk perluasannya.

Hukum acara pidana yang dikenal dengan hukum pidana formal merupakan suatu hukum yang mengatur tata cara dalam penyelenggaraan Hukum Pidana Material, agar mendapatkan putusan Hakim dan dapat dilaksanakan isi putusan tersebut. Undang- Undang Nomor 8 Tahun 1981 tentang hukum acara pidana menjadi dasar dalam penyelengaraannya. Ketentuan dalam hukum acara pidana tertuang didalam Kitab Undang-Undang Hukum Acara Pidana (KUHAP) yang diundangkan berlakunya sejak tanggal 31 desember 1981 melalui lembaran Negara Republik Indonesia Nomor 76, tambahan lembaran Negara Nomor 3209.

Kodifikasi hukum pidana ini bertujuan untuk menggantikan Reglemen Indonesia Baru (RIB) tentang acara pidana yang sudah tidak sesuai dengan perkembangan masyarakat dalam melindungi hak-hak asasi manusia. Selain itu, hal ini berfungsi untuk mengatasi masalah dalam melindungi kepentingan umum. Pasal 2 KUHAP menyatakan bahwa KUHAP berlaku bagi lingkup peradilan umum dalam pelaksanaan tata cara peradilan. Asas-asas hukum pidana menjadi dasar berlakunya KUHAP dan hanya peradilan umumlah yang memiliki wewenang mengadili tindak pidana, kecuali terdapat ketentuan lain di dalamnya.

RUU KUHAP menjadi cara dalam memperbaharui sistem hukum di Indonesia, khususnya hukum Acara Pidana Indonesia, agar penegak hukum ditempatkan sesuai dengan tugas, fungsi, dan wewenangnya dan bisa beradaptasi dengan susunan ketatanegaraan, perkembangan teknologi dan masyarakat, serta konvensi- konvensi internasional yang sudah diratifikasi oleh Indonesia.

\section{Kesimpulan}

1. Eksistensi CCTV pada pembuktian perkara tindak pidana umum adalah dapat menjadi alat 
bukti yang sah apabila dilakukan dalam rangka penegakan hukum atas permintaan kepolisian, kejaksaan, dan/atau institusi penegak hukum lainnya yang diitetapkan berdasarkan undang-undang. Alat bukti ini digunakan dalam mendukung proses peradilan yang menunjukkan secara jelas kejadian di tempat perkara, sehingga didalam proses peradilan, rekaman CCTV menjadi suatu alat bukti penunjang pembuktian disamping alat bukti lainnya untuk memperoleh kebenaran suatu perkara yang terjadi dan memiliki kekuatan hukum tetap.

2. Kebijakan kriminal tentang CCTV sebagai alat bukti menggunakan sarana penal dan non penal. Sarana kebijakan kriminal dengan sarana penal, merupakan tindakan nyata aparat penegak hukum, khususnya setelah diberlakukan Putusan Mahkamah Konstitusi (MK) Nomor: 21/PUU-XIV/2016. Sedangkan sarana non penal yaitu menitik beratkan pada sifat preventif, dalam hal ini penggunaan CCTV sebagai alat bukti merupakan upaya yang dilakukan oleh kepolisian dalam menanggulangi sebelum adanya pengaturan dalam KUHAP.

\section{A. Buku}

\section{DAFTAR PUSTAKA}

Arief, Barda Nawawi. (2001). Masalah Penegakan Hukum dan Kebijakan Penanggulangan Kejahatan. Bandung: Citra Aditya Bakti.

Arif, Barda Nawawi. (2004). Kebijakan Hukum Pidana. Bandung: Citra Aditya Bakti.

Hiariej, Eddy O.S. 2012. Teori dan Hukum Pembuktian, Cetakan ke-1, Jakarta: Erlangga.

Marselus Pasha Lelyemin, F. Nugroho dan Edy Hartadi. (2007). Kedudukan Rekamaí Video sebagaiAlat Bukti Dalam Hukum Acara Pidana di Indonesia. Jakarta: Fakultas Hukum Unika Atmajaya.

Mulyadi, Lilik. (2007). Hukum Acara Pidana. Bandung: Citra Aditya Bakti

R. Subekti. (2005). Hukum Pembuktian, Cetakan ke-15, Jakarta: Pradnya Paramita.

Waluyo, Bambang. (1992). Sistem Pembuktian Dalam Peradilan Indonesia. Jakarta: Sinar Grafika.

\section{B. Internet}

http://www.hukumonline.com/klinik/detail/cl6915/alat-bukti-rekaman. Diakses $\quad$ Selasa 6 September 2016.

\section{Sumber Lainnya}

Hasil wawancara dengan Akhmad Suhel. Hakim Pengadilan Negeri Tanjung Karang. Rabu, 18 Januari 2017.

Hasil wawancara dengan Eddy Rifai. Akademisi Hukum Pidana Fakultas Hukum Universitas Lampung. Sabtu, 4 Maret 2017.

Hasil wawancara dengan Eko Setiawan. Personil Bagian IT Polda Lampung. Kamis, 19 Januari 2017.

Hasil wawancara dengan Eva Mayanti. Penuntut Umum pada Kejaksaan Negeri Bandar Lampung. Senin, 16 Januari 2017.

Hasil wawancara dengan Kurnia Muludi. Ahli Telematika Jurusan Ilmu Komputer Fakultas MIPA Universitas Lampung. Jumat, 3 Maret2017. 